\title{
Real-Time Polymerase Chain Reaction for Quantitative Detection of Histamine-Producing Bacteria: Use in Cheese Production
}

\author{
M. Fernández, B. del Río, D. M. Linares, M. C. Martín, and M. A. Alvarez ${ }^{1}$ \\ Instituto de Productos Lácteos de Asturias (IPLA), Consejo Superior de Investigaciones Científicas (CSIC), 33300 Villaviciosa, Asturias, Spain
}

\begin{abstract}
Biogenic amines are toxic substances that appear in foods and beverages as a result of AA decarboxylation. The enzyme histidine decarboxylase catalyzes the decarboxylation of histidine to histamine, the biogenic amine most frequently involved in food poisoning. The aim of the present work was to develop a real-time quantitative PCR assay for the direct detection and quantification of histamine-producing strains in milk and cheese. A set of primers was designed, based on the histidine decarboxylase gene sequence of different gram-positive bacteria. The results show the proposed procedure to be a rapid (total processing time $<2 \mathrm{~h}$ ), specific and highly sensitive technique for detecting potential histamine-producing strains. Chromatographic methods (HPLC) verified the capacity of real-time quantitative PCR to correctly quantify histamine accumulation.
\end{abstract}

Key words: histamine detection, lactic acid bacteria, cheese, real-time quantitative polymerase chain reaction

\section{INTRODUCTION}

Biogenic amines (BA) are low molecular weight organic compounds with different biological activities. Although they have important metabolic roles in living cells, high concentrations of BA in foodstuffs can induce a range of toxicological effects (Silla Santos, 1996). These problems are particularly severe in individuals who, for whatever reason, are deficient in diamine oxidase, the histamine-degrading enzyme (Bodmer et al., 1999).

Histamine poisoning is the most common foodborne problem caused by BA. At nontoxic doses, foodborne histamine can cause intolerance symptoms such as diarrhea, hypotension, headache, pruritus, and flushes. Just $75 \mathrm{mg}$ of histamine, a quantity commonly present in normal meals, can induce symptoms in the majority

Received February 21, 2006

Accepted April 14, 2006.

${ }^{1}$ Corresponding author: maag@ipla.csic.es of healthy persons with no history of histamine intolerance (Wohrl et al., 2004). Histamine is formed by histidine decarboxylation in a variety of foods, including raw fish, fish products, wine, fermented meat, and cheese. Cheese is a histamine-rich food and may contain up to $500 \mathrm{mg} / \mathrm{kg}$ (Roig-Sagués et al., 2002). In raw fish products, histamine is formed by the histidine decarboxylation activity of gram-negative enteric bacteria such as Morganella morganii, Klebsiella spp., and Enterobacter spp. (López Sabater et al., 1994; Kim et al., 2001). However, in fermented products, such as cheese and wine, it is mainly produced by gram-positive lactic acid bacteria (LAB). These microorganisms are frequently associated with the raw materials used and, in some instances, may even be part of the starter culture (Novella Rodríguez et al., 2002).

The gene encoding histidine decarboxylase $(h d c A)$ has been identified in different gram-positive bacteria (Martín et al., 2005). Histidine decarboxylase used to be part of a cluster that included a gene of unknown function $(h d c B)$ and a histidine-histamine antiporter gene $(h d c C)$. Chromosomal localization of the $h d c$ cluster has been demonstrated in Lactobacillus buchneri B301 (Martín et al., 2005) and has been suggested, based on the stability of histamine production, in Pediococcus parvulus 276 and Lactobacillus hilgardii 321 (Landete et al., 2005). Only in the case of $L$. hilgardii 006 has a plasmid location of the $h d c A$ gene been proposed (Lucas et al., 2005).

Because histamine can cause food poisoning, several quantitative and qualitative methods have been developed for its detection, mainly based on liquid chromatography or capillary electrophoresis (Cinquina et al., 2004). Early detection of histamine-producing bacteria is very important in the food industry. Microbiological screening methods have been developed based on the use of a differential medium containing a $\mathrm{pH}$ indicator (Maijala, 1993; Bover-Cid and Holzapfel, 1999). However, DNA-based procedures, which focus on the nucleic acid composition of the bacterial genome, are subject to less variability and are less time-consuming than phenotypic characterization. Polymerase chain reaction offers a rapid and specific means of detecting and identifying histamine-producing bacteria. Different 
sets of primers have been developed for detecting grampositive (Le Jeune et al., 1995; Coton and Coton, 2005; Landete et al., 2005) and gram-negative (Takahashi et al., 2003) types. However, although sensitive and specific under optimized conditions, conventional PCR has one drawback-the need to analyze the data by traditional end-point analysis. Real-time quantitative PCR (qPCR) is a potential alternative. This would allow continuous monitoring of the PCR amplification process (Wittwer et al., 1997) and, under appropriate conditions, quantification of the template. In addition, real-time methods are considerably less time-consuming than regular PCR. Real-time qPCR has been successfully used to detect pathogenic microorganisms in different foods (McKillip and Drake, 2004), including milk (Gillespie and Oliver, 2005), and also to quantify bacterial genera and species in fermented milk products (Furet et al., 2004) and the intestine (Huijsdens et al., 2002).

The present study proposes a real-time qPCR method for the direct detection and quantification of histamineproducing LAB in culture media, milk, and curd. The proposed method was optimized to quantify the presence of histamine-producing microorganisms in cheeses and during the cheese-making process.

\section{MATERIALS AND METHODS}

\section{Bacterial Strains and Culture Conditions}

Table 1 shows the strains used in this study. Lactococcus and Enterococcus were routinely grown at $30^{\circ} \mathrm{C}$ in M17 broth (Oxoid, Basingstoke, UK) supplemented with $0.5 \%$ glucose. Pediococcus and L. hilgardii were grown at $28^{\circ} \mathrm{C}$ in de Man, Rogosa, Sharpe broth (MRS; Oxoid). Lactobacillus buchneri strains were grown at $37^{\circ} \mathrm{C}$ in LAPTg (Raibaud et al., 1961) and Oenococcus at $30^{\circ} \mathrm{C}$ in MRS (Oxoid). In some experiments, L. buchneri was grown in skimmed milk (Oxoid). The number of colony-forming units was determined by plating different dilutions of the cultures on LAPTg agar plates and incubating them aerobically for $24 \mathrm{~h}$ at $37^{\circ} \mathrm{C}$.

\section{Construction of Plasmid pM11}

The $h d c A-h d c B$ genes from $L$. buchneri B301 were amplified by PCR with the primers 5'-AGGAATTCCTTTCTATATCTGGG-3' and 5'-TTATCTACTCGAGACTAATTAAC-3', which contain an EcoRI and XhoI site, respectively (underlined). A 2.04-kb PCR fragment was obtained and cloned as an EcoRI-XhoI fragment in pNZ124 (Platteeuw et al., 1994), resulting in plasmid pM11.

\section{Preparation of the Real-Time qPCR Samples}

DNA. When used as a template, DNA was isolated from cells grown in culture media as described by de Vos and Simons (1994). Template DNA was also isolated from cheese. Five grams of cheese was taken and homogenized mechanically in $40 \mathrm{~mL}$ of $2 \%$ sodium citrate in a Lab-Blender 400 stomacher (Seward Medical, London, UK) for $1 \mathrm{~min}$. DNA was extracted from the homogenate following the method of Ogier et al. (2002) and resuspended in $25 \mathrm{~m} M$ Tris-HCl buffer in a final volume of $150 \mu \mathrm{L}$.

Large-scale isolation of plasmid DNA from Lactococcus lactis was performed with the Plasmid Midi Kit (Qiagen, Hilden, Germany) according to the manufacturer's instructions. Ten-fold serial dilutions (in MilliQ water; Millipore, Billerica, MA) of this DNA were prepared for use as template material.

Cell Suspensions of Medium, Milk, and Curd. When cell suspensions were used as templates, $1 \mathrm{~mL}$ of medium or milk culture was disrupted with zirconium beads in a Bio101 Fast Prep apparatus (Q-Biogen, Montreal, Canada; two treatments of $30 \mathrm{~s}$ each, with intervals of 1 min on ice between treatments). Cell debris was removed by centrifugation. In all cases, the bacterial suspensions were plated for enumeration.

Colonies. Real-time $\mathrm{qPCR}$ was also performed using colonies isolated from plates. In these experiments, one colony was resuspended in $50 \mu \mathrm{L}$ of MilliQ water, and 10 -fold serial dilutions were prepared and used as a template.

\section{Real-Time qPCR Conditions}

The forward and reverse primers used were obtained from Sigma Genosys (Haverhill, UK). Real-time qPCR was performed using the SYBR Green PCR Master Mix kit (Applied Biosystems, Warrington, UK). The 20- $\mathrm{L}$ reaction volume included $1 \mu \mathrm{L}$ of template, $10 \mu \mathrm{L}$ of SYBR Green PCR Master Mix (containing ROX as a passive reference), and $900 \mathrm{nM}$ of each primer. Amplification and detection were performed using an ABI Prism Fast 7500 (Applied Biosystems) sequence detection system under the following conditions: $2 \mathrm{~min}$ at $50^{\circ} \mathrm{C}$, followed by $10 \mathrm{~min}$ at $95^{\circ} \mathrm{C}$, followed by 40 cycles, $15 \mathrm{~s}$ at $95^{\circ} \mathrm{C}$, and $1 \mathrm{~min}$ at $58^{\circ} \mathrm{C}$. The cycle number during which the fluorescence signal crossed the chosen cycle threshold $\left(\mathbf{C}_{\mathbf{T}}\right.$; in this case the default set by the manufacturer) was noted. All samples were processed in triplicate (independent procedures). Positive controls using the plasmid pM11 as a template were included in all tests. Negative controls were also included; these involved all the elements of the reaction mixture except the template DNA. Melting temperature analysis of the 
Table 1. Strains used in this study ${ }^{1}$

\begin{tabular}{|c|c|c|c|c|}
\hline Strain & $\begin{array}{l}\text { Histamine } \\
\text { producer }\end{array}$ & PCR & $\begin{array}{l}\text { Origin } \\
\text { of the } \\
\text { strain }\end{array}$ & Source \\
\hline Lactobacillus buchneri B301 & + & + & Cheese & NIZO \\
\hline L. buchneri B 302 & + & + & Cheese & NIZO \\
\hline L. buchneri B303 & + & + & Cheese & NIZO \\
\hline L. buchneri DSM5987 & + & + & Cheese & DSMZ \\
\hline Lactobacillus plantarum NCIMB8826 & - & - & Human saliva & NCIMB \\
\hline Lactobacillus casei 393 & - & - & Cheese & ATCC \\
\hline Lactobacillus brevis CECT3810 & - & - & Cheese & CECT \\
\hline Lactobacillus hilgardii 321 & + & + & Wine & University of Valencia (Spain) \\
\hline Enterococcus $15 \mathrm{~A}$ & + & + & Cheese & IPLA \\
\hline Enterococcus faecalis CNRZ1535 & - & - & Cheese & CNRZ \\
\hline Enterococcus durans L21 & _ & _- & Cheese & IPLA \\
\hline Oeonococcus oeni 206 & + & + & Wine & University of La Rioja (Spain) \\
\hline O. oeni 212 & + & + & Wine & University of La Rioja (Spain) \\
\hline Lactococcus lactis IPLA655 & - & - & Cheese & IPLA \\
\hline Lc. lactis MG1363 & - & - & Cheese & Gasson, 1983 \\
\hline Pediococcus parvulus 276 & + & + & Wine & University of Valencia (Spain) \\
\hline L. plantarum L 441 & - & - & Cheese & IPLA \\
\hline L. plantarum $\mathrm{C} 3-8$ & _ & - & Cheese & IPLA \\
\hline
\end{tabular}

${ }^{1}$ NIZO = Netherlands Institute of Dairy Research (Ede, The Netherlands); DSMZ = Deutsche Sammlung von Mikroorganismen und Zellkulturen GmbH (Braunschweig, Germany); NCIMB = National Collections of Industrial, Marine and Food Bacteria (Bucksburn, Aberdeen, UK); ATCC = American Type Culture Collection (Manassas, VA); CECT = Coleccion Española de Cultivos TipoFederico Uruburu, Universidad de Valencia (Burjasot, Spain); IPLA = Instituto de Productos Lácteos de Asturias (Asturias, Spain); CNRZ = Centre National de Recherches Zootechniques, l'Institut National de la Recherche Agronomique, Unitè de Recherches Laitières (Jouy-en-Josas Cedex, France).

PCR products was performed to determine the specificity of the PCR reaction.

\section{Analytical Procedure}

Amine quantification was performed by reversedphase-HPLC using a Waters liquid chromatograph controlled by Millenium 32 software (Waters, Milford, MA). One-gram amounts of all food samples were homogenized for $2 \mathrm{~min}$ at 20,000 rpm using an UltraTurrax homogenizer (Omni International, Waterbury, CT). Histamine was extracted and quantified using the method of Krause et al. (1995).

\section{RESULTS}

\section{Design of Gram-Positive hdc Consensual Primers}

The $h d c A$ gene was chosen as a target for detecting and quantifying the histamine-producing bacteria. The $h d c A$ sequences of the gram-positive bacteria Tetragenococcus muriaticus JCM 1006, Oeonococcus oeni IOEB 9204, Lactobacillus 30a, L. buchneri B301, and L. hilgardii 0006 (GenBank accession numbers: AB125629, U58865, J02613, AJ749838, and AY651779, respectively) were compared. Sequence alignment was performed using the CLUSTAL $\mathrm{W}$ algorithm (Thompson et al., 1994). This, plus the identification of highly conserved regions, allowed the design of the primer pair
Hdc1 (5'-TTGACCGTATCTCAGTGAGTCCAT-3') plus Hdc2 (5'-ACGGTCATACGAAACAATACCATC-3'). These primers amplified a 174-bp fragment inside $h d c A$.

\section{Assay Specificity}

The specificity of the assays was tested using purified DNA from target and nontarget bacteria. No amplification was observed when DNA from nontarget bacteria was used as a template (Table 1). The influence of nonspecific background DNA on assay performance was also examined by monitoring the amplification of different amounts of target DNA in the presence of $200 \mathrm{ng}$ of total genomic DNA from different non-histamineproducing bacteria. Neither the amplification profiles nor the efficiency of the assay with target DNA from L. buchneri B301 was altered by inclusion of nonspecific DNA (data not shown).

Assays were also performed using isolated colonies of histamine-producing and nonproducing species. Only the DNA of target bacteria was amplified.

\section{Sensitivity and Quantification Range}

The quantification limits of the assay were determined using plasmid DNA isolated from an overnight culture of the Lc. lactis strain carrying plasmid pM11. 
Amplification reactions were performed with a range of DNA concentrations equivalent to 1 to $10^{6}$ target molecules (on the basis of the molecular size of the plasmid and the DNA concentration, determined by spectrophotometry). The standard curve showed a linear relationship between $\log$ input DNA and $\mathrm{C}_{\mathrm{T}}$ (Figure $1 \mathrm{~A})$. The slope of the curve was -3.56 and the regression coefficient $\left(\mathrm{R}^{2}\right)$ was 0.9993 . The detection limit was 1 plasmid molecule $\left[\mathrm{C}_{\mathrm{T}} 30.09\right.$, standard deviation (SD) 0.21 .

The sensitivity of the proposed method was examined using pure cultures instead of DNA. One milliliter of each concentration of a 10-fold-diluted overnight culture of L. buchneri B301 $\left(10^{9} \mathrm{cfu} / \mathrm{mL}\right)$ was disrupted as indicated above and used to provide template DNA. The standard curve showed a linear relationship between $\log$ input cfu and $\mathrm{C}_{\mathrm{T}}$ (Figure 1B). The slope of the curve was -3.39 , and $R^{2}$ was 0.995 . The detection limit was $10^{1} \mathrm{cfu} / \mathrm{mL}\left(\mathrm{C}_{\mathrm{T}} 33.47, \mathrm{SD} 0.78\right)$.

\section{Sensitivity and Detection Limits in Milk and Curd}

Experiments were conducted to determine the lower detection limit for histamine-producing bacteria in milk and curd. Serial dilutions were made of a 6 -h-old milk culture containing $4 \times 10^{8} \mathrm{cfu} / \mathrm{mL}$ of L. buchneri B301 and samples of each concentration were disrupted as indicated above. The standard curve showed a linear relationship between log input cfu and the $\mathrm{C}_{\mathrm{T}}$; the slope of the curve was -3.36 and the $\mathrm{R}^{2}$ value was 0.998 . The detection limit was $4 \times 10^{2} \mathrm{cfu} / \mathrm{mL}\left(\mathrm{C}_{\mathrm{T}} 32.38\right.$, SD 0.15 ; Figure 1C). For curd, an overnight milk culture of the producer strain containing $2 \times 10^{8} \mathrm{cfu} / \mathrm{mL}$ was disrupted and serial dilutions of this suspension were used as templates for the reaction. The slope of the curve was -3.38 and the $\mathrm{R}^{2}$ coefficient was 0.9992 . The detection limit was $2 \times 10^{2}\left(\mathrm{C}_{\mathrm{T}} 31.79\right.$, SD 0.24; Figure $\left.1 \mathrm{D}\right)$.

\section{Detection of Histamine-Producing Bacteria During Cheese Manufacture}

Cabrales, a blue cheese with a high histamine concentration (Roig-Sagués et al., 2002), was used as a model in which to detect the presence and follow the development of histamine-producing strains during commercial production. Samples from 4 independent cheeses were taken at different points in the manufacturing process and analyzed by real-time qPCR and HPLC. Real-time qPCR analysis detected histamine-producing bacteria in all the samples analyzed, including the curd and cheese during the first days of ripening. A large drop in the $\mathrm{C}_{\mathrm{T}}$ values was observed between the milk and cheese samples on $d 7$ of ripening, indicating a strong increase in the number of histamine-producing

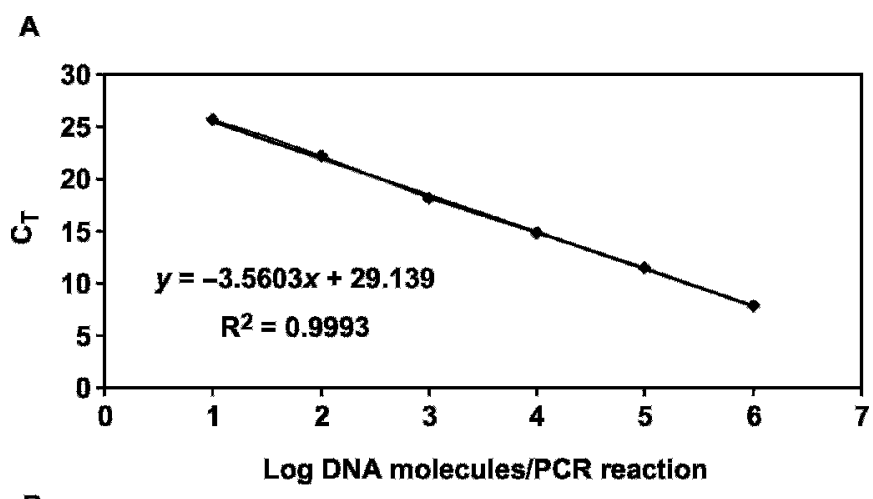

$\mathbf{B}$

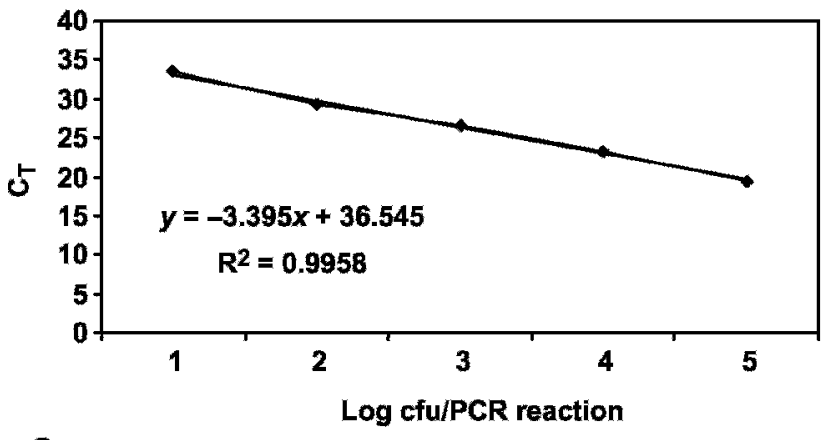

C

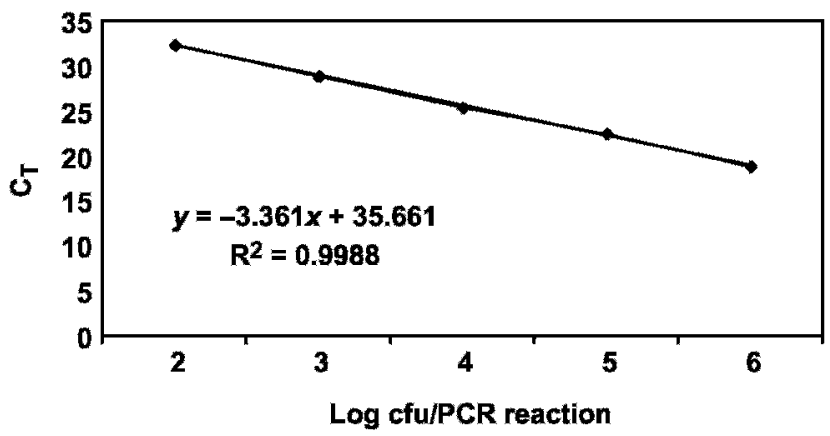

D

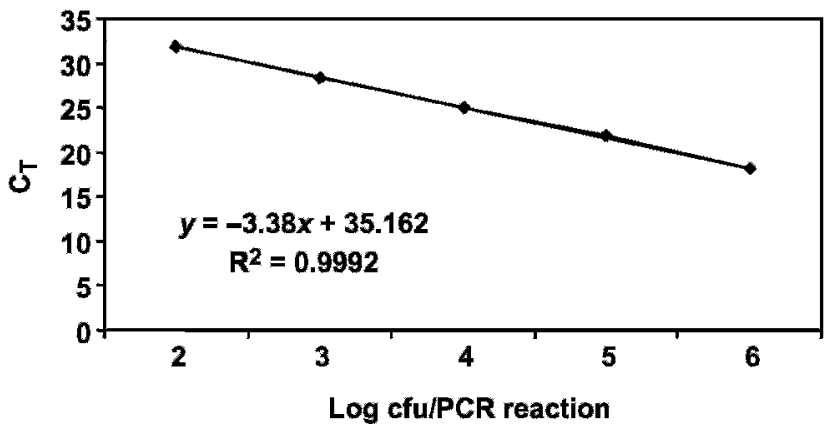

Figure 1. (A) Real-time quantitative PCR (real-time qPCR) analysis of 10 -fold serial dilutions of plasmid pM11 DNA. Cycle threshold $\left(\mathrm{C}_{\mathrm{T}}\right)$ values are plotted against the calculated plasmid copy number. Real-time qPCR analysis of 10 -fold serial dilutions of $L$. buchneri in (B) media, (C) milk, and (D) curd. $\mathrm{C}_{\mathrm{T}}$ values were plotted against the cfu count. 
Table 2. Quantification by HPLC of histamine and histidine, and detection of histidine-producing bacteria by real-time quantitative PCR (qPCR), during cheese manufacture ${ }^{1}$

\begin{tabular}{llcc}
\hline Sample & $\begin{array}{l}\text { Real-time } \\
\mathrm{qPCR}, \mathrm{C}_{\mathrm{T}}\end{array}$ & $\begin{array}{l}\text { Histidine, } \\
\mathrm{mg} / \mathrm{kg}\end{array}$ & $\begin{array}{l}\text { Histamine, } \\
\mathrm{mg} / \mathrm{kg}\end{array}$ \\
\hline Milk & 35.5 & 1.56 & 0 \\
Curd & 25.94 & 1.78 & 0 \\
Cheese & & & \\
$3 \mathrm{~d}$ & 20.6 & 3.68 & 0 \\
$7 \mathrm{~d}$ & 19.94 & 16.61 & 11.71 \\
$15 \mathrm{~d}$ & 19.35 & 2.76 & 43.78 \\
$30 \mathrm{~d}$ & 19.76 & 4.75 & 84.78 \\
$60 \mathrm{~d}$ & 18.95 & 52.09 & 820.72 \\
$90 \mathrm{~d}$ & 17.57 & 93.88 & $1,135.36$ \\
\hline
\end{tabular}

${ }^{1} \mathrm{C}_{\mathrm{T}}=$ Cycle threshold.

bacteria. However, histamine was not detected by HPLC until d 7 of ripening, even in the cheeses with the highest final histamine concentrations. Table 2 shows the results obtained with the cheeses showing the higher histamine concentrations.

\section{Quantification of Histamine-Producing Bacteria in Commercial Cheeses and Relationship with Histamine Content}

This real-time qPCR method provides a good way of determining the numbers of histamine-producing bacteria in commercial cheese samples and their relation to histamine levels. Different cheeses, purchased at a market, were analyzed by HPLC and real-time qPCR; the results are shown in Table 3 . In all positive realtime qPCR samples, the presence of histamine was confirmed by HPLC. However, in cheeses in which histamine was not detected by HPLC, the real-time qPCR result was negative. The histamine concentration and $\mathrm{C}_{\mathrm{T}}$ value were inversely related.

\section{DISCUSSION}

The rapid, specific, and sensitive detection of microorganisms has always been a challenge to the food indus-

Table 3. Detection of histamine-producing bacteria by real-time quantitative PCR (qPCR), and the histamine concentration determined by HPLC, in different types of cheese ${ }^{1}$

\begin{tabular}{llc}
\hline Cheese type & $\begin{array}{l}\text { Real-time } \\
\text { qPCR, } \mathrm{C}_{\mathrm{T}}\end{array}$ & $\begin{array}{c}\mathrm{HPLC}, \\
\mathrm{mg} / \mathrm{kg}\end{array}$ \\
\hline Gorgonzola & UD & UD \\
Saint Pauling & UD & UD \\
Pria & UD & UD \\
Saint Albary & UD & 985.56 \\
Roncal & 15.24 & 998.34 \\
Idiazabal & 15.58 & 135.36 \\
Cabrales & 17.57 & 508.84 \\
Cabrales & 25.04 & 573.06 \\
Cabrales & 25.41 &
\end{tabular}

${ }^{1} \mathrm{C}_{\mathrm{T}}=$ Cycle threshold; UD = undetected. try. Although no standards or guidelines regarding permissible concentrations of histamine in fermented foods have been established, the US Food and Drug Administration has set a tolerance limit in fresh fish of 100 $\mathrm{mg} / \mathrm{kg}$, whereas European legislation (Directive 91/493/ EEC; European Union, 1991) establishes a maximum histamine concentration of 100 to $200 \mathrm{mg} / \mathrm{kg}$ in fishery products. In general, concentrations greater than 100 $\mathrm{mg} / \mathrm{kg}$ are not recommended, especially for consumers with a deficiency of the detoxification system. Recently, Wohrl et al. (2004) concluded that $75 \mathrm{mg}$ of pure histamine, a quantity that can be ingested in a single portion of affected cheese, can provoke immediate as well as delayed symptoms in $50 \%$ of healthy volunteers. Rapid and reliable methods are therefore needed for screening food samples. This is the first study to detect and identify histamine-producing LAB using SYBR Green realtime qPCR.

Some strains of LAB synthesize histamine, an ability strictly related to the possession of the gene $h d c A$ (Landete et al., 2005; Lucas et al., 2005). The $h d c A$ gene has been identified in different gram-positive and gramnegative bacteria. Alignment of the sequences shows a strong identity among the $h d c A$ genes of gram-positive bacteria, which are clearly different from those of gramnegative bacteria (Kamath et al., 1991). Several pairs of primers have been described for the PCR detection of gram-positive histidine decarboxylase-producing $\left(\right.$ HDC $^{+}$) strains (Le Jeune et al., 1995; Coton and Coton, 2005; Landete et al., 2005). In the present study, the design of $\mathrm{Hdc} 1$ and Hdc2, primers more suited to realtime qPCR, was based on the sequences of LAB $h d c A$ genes. These primers amplified a specific fragment, even with histamine-producing strains whose $h d c A$ sequences were unknown (e.g., the Enterococcus strain; Table 1). This specificity is required for accurate quantitative measurements of target microorganisms responsible for histamine production in fermented foods. With this method, $\mathrm{HDC}^{+}$bacteria can be identified directly as colonies or in culture media, milk, and curd without the need for previous DNA extraction.

The $h d c A$ gene copy number and $\mathrm{C}_{\mathrm{T}}$ values correlated well (Figure 1A), although quantification using plasmids provided the most accurate results, because absolute copy numbers can be calculated from the DNA concentration. The method was also used to detect histamine-producing bacteria in different media and milk-always without the need for DNA extraction.

The detection limit of the proposed method is comparable to that reported in other real-time qPCR studies (Nogva et al., 2000; Hein et al., 2001). The difference in the detection limit seen for the milk and curd and for the culture media may be explained by the presence of inhibitors in the dairy substrates (Powell et al., 1994). 
However, the method appears to be sufficiently sensitive, because histamine was not detected in any negative real-time qPCR samples. Moreover, the entire process takes only approximately $2 \mathrm{~h}$, and 96 samples can be processed simultaneously. This could be a boon to the dairy industry because microbiological methods require more than $24 \mathrm{~h}$ to complete. In addition, the procedure allows the identification of potential histamine-producing LAB, which would be useful when screening for potential starter strains. Another important advantage of this method is that it can be used at any point in the manufacturing process, even when histamine is still undetectable by other methods.

The results show that the number of $\mathrm{HDC}^{+}$bacteria increases at the beginning of the Cabrales ripening process, with no variation after $3 \mathrm{~d}$. These results agree with the increase in the number of LAB reported by Flórez and Mayo (2005). However, the histamine concentration during the first few days of ripening is so low that it is undetectable by HPLC. The absence of histamine during these initial stages is probably due to the low concentration of histidine, until it is released from casein by proteases (Table 2). In the last stages of ripening, the histamine concentration increases disproportionately compared with the $\mathrm{C}_{\mathrm{T}}$ value. This appears to be more related to an increase in the histidine concentration (Table 2) and to a histamine accumulation effect than to any increase in the number of histamine-producing microorganisms. Nevertheless, it is important to mention that low $\mathrm{C}_{\mathrm{T}}$ values at early ripening phases can be used to predict a high histamine accumulation in the final products.

Real-time qPCR was also assayed with samples of different cheeses. A relationship was observed between the $\mathrm{C}_{\mathrm{T}}$ values and histamine concentrations (Table 3 ). Although not linear, this is probably due to the availability of histidine and the accumulation of histamine during the ripening process. However, a good correlation was seen between the presence or absence of histamine and the real-time qPCR results in all cases.

In conclusion, the proposed method offers a rapid and simple way of characterizing the LAB in different types of dairy substrates. It could be used to prevent the selection of histamine-producing strains as starter cultures. It is much faster than any microbiological procedure for the detection and quantification of $\mathrm{HDC}^{+}$ strains in milk, curd, and cheese, and it even allows an estimation of the histamine content of these substrates, because $\mathrm{C}_{\mathrm{T}}$ values under 26 can be related to histamine concentrations higher than $500 \mathrm{mg} / \mathrm{kg}$. In this respect, the method may be used for the rapid screening of food samples. For the exact quantification of positive samples, the method should be complemented by other analytical procedures. Because $\mathrm{HDC}^{+} \mathrm{LAB}$ of different ori- gins were detected in this study, the proposed method might be of use with other types of fermented foods and drinks.

\section{ACKNOWLEDGMENTS}

We are grateful to the Netherlands Institute of Dairy Research (NIZO, Ede, the Netherlands) for providing the strains L. buchneri B301, L. buchneri B302, and $L$. buchneri B303; Sergi Ferrer for providing the strains L. hilgardii and P. parvulus; and Fernanda Ruiz Larrea for providing the strains $O$. oeni 206 and O. oeni 212 . We also thank Baltasar Mayo for the Cabrales samples used in this study, and Adrian Burton for proofreading the English. This work was supported by European Union research grant no. QRLT-2002-02388. D. M. Linares was the recipient of a fellowship from the Spanish Ministry of Education and Science. M. Fernández, B. del Río, and M. C. Martín are beneficiaries of I3P CSIC contracts financed by the European Social Fund.

\section{REFERENCES}

Bodmer, S., C. Imark, and M. Kneubühl. 1999. Biogenic amines in foods: Histamine and food processing. Inflamm. Res. 48:296-300.

Bover-Cid, S., and W. H. Holzapfel. 1999. Improved screening procedure for biogenic amine production by lactic acid bacteria. Int. J. Food Microbiol. 53:33-41.

Cinquina, A. L., F. Longo, A. Cali, L. De Santis, R. Baccelliere, and R. Cozzani. 2004. Validation and comparison of analytical methods for the determination of histamine in tuna fish samples. J. Chromatogr. A. 1032:79-85.

Coton, E., and M. Coton. 2005. Multiplex PCR for colony direct detection of Gram-positive histamine- and tyramine-producing bacteria. J. Microbiol. Methods 63:296-304.

de Vos, W. M., and G. Simons. 1994. Gene cloning and expression systems in lactococci. Pages 52-105 in Genetics and Biotechnology of Lactic Acid Bacteria. M. J. Gasson and W. M. de Vos, ed. Chapman \& Hall, London, UK.

European Union. 1991. Directive 91/493/EEC: Directive of July 22, 1991 establishing standards to be applied to the production and commercialization of fishery products. Off. J. L 268:15-34.

Flórez, B., and B. Mayo. 2005. Microbial characterisation of the traditional Spanish blue-veined Cabrales cheese: Identification of dominant lactic acid bacteria. Eur. Food Res. Technol. doi:10.1007/ s00217-005-0230-8.

Furet, J. P., P. Quenee, and P. Tailliez. 2004. Molecular quantification of lactic acid bacteria in fermented milk products using real-time quantitative PCR. Int. J. Food Microbiol. 97:197-207.

Gasson, M. J. 1983. Plasmid complements of Streptococcus lactis NCDO 712 and other lactic streptococci after protoplast-induced curing. J. Bacteriol. 154:1-9.

Gillespie, B. E., and S. P. Oliver. 2005. Simultaneous detection of mastitis pathogens, Staphylococcus aureus, Streptococcus uberis, and Streptococcus agalactiae, by multiplex real-time polymerase chain reaction. J. Dairy Sci. 88:3510-3518.

Hein, I., D. Klein, A. Lehner, A. Bubert, E. Brandl, and M. Wagner. 2001. Detection and quantification of the iap gene of Listeria monocytogenes and Listeria innocua by a new real-time quantitative PCR assay. Res. Microbiol. 152:37-46.

Huijsdens, X. W., R. K. Linskens, M. Mak, S. G. Meuwissen, C. M. Vandenbroucke-Grauls, and P. H. Savelkoul. 2002. Quantification of bacteria adherent to gastrointestinal mucosa by real-time PCR. J. Clin. Microbiol. 40:4423-4427. 
Kamath, A. V., G. L. Vaaler, and E. E. Snell. 1991. Pyridoxal phosphate dependent histidine decarboxylases. Cloning, sequencing, and expression of genes from Klebsiella planticola and Enterobacter aerogenes and properties of the overexpressed enzyme. J. Biol. Chem. 266:9432-9437.

Kim, S. H., K. G. Field, M. T. Morrissey, R. J. Price, C. I. Wei, and H. An. 2001. Source and identification of histamine-producing bacteria from fresh and temperature-abused albacore. J. Food Prot. 64:1035-1044.

Krause, I., A. Bockhardt, H. Neckermann, T. Henle, and H. Klostermeyer. 1995. Simultaneous determination of amino acids and biogenic amines by reversed-phase high-performance liquid chromatography of the dabsyl derivatives. J. Chromatogr. A. 715:67-79.

Landete, J. M., S. Ferrer, and I. Pardo. 2005. Which lactic acid bacteria are responsible for histamine production in wine? J. Appl. Microbiol. 99:580-586.

Le Jeune, C., A. Lonvaud-Funel, B. Ten Brink, H. Holstra, and J. M. B. M. van der Vossen. 1995. Development of a detection system for histidine decarboxylating lactic acid bacteria based on DNA probes, PCR and activity test. J. Appl. Bacteriol. 78:316-326.

López-Sabater, E. I., J. J. Rodríguez-Jerez, M. Hernández-Herrero, and M. T. Mora-Ventura. 1994. Evaluation of histidine decarboxylase activity of bacteria isolated from sardine (Sardina pilchardus) by an enzymic method. Lett. Appl. Microbiol. 19:70-75.

Lucas, P. M., W. A. Wolken, O. Claisse, J. S. Lolkema, and A. LonvaudFunel. 2005. Histamine-producing pathway encoded on an unstable plasmid in Lactobacillus hilgardii 0006. Appl. Environ. Microbiol. 71:1417-1424.

Maijala, R. L. 1993. Formation of histamine and tyramine by some lactic acid bacteria in MRS-broth and modified decarboxylation agar. Lett. Appl. Microbiol. 17:40-43.

Martín, M. C., M. Fernández, D. M. Linares, and M. A. Alvarez. 2005. Sequencing, characterization and transcriptional analysis of the histidine decarboxylase operon of Lactobacillus buchneri. Microbiology 151:1219-1228.

McKillip, J. L., and M. Drake. 2004. Real-time nucleic acid-based detection methods for pathogenic bacteria in food. J. Food Prot. 67:823-832.

Nogva, H. K., K. Rudi, K. Naterstad, A. Holck, and D. Lillehaug. 2000. Application of 5'-nuclease PCR for quantitative detection of Listeria monocytogenes in pure cultures, water, skim milk, and unpasteurized whole milk. Appl. Environ. Microbiol. 66:42664271.

Novella-Rodríguez, S., M. T. Veciana-Nogués, A. X. Roig-Sagués, A. J. Trujillo-Mesa, and M. C. Vidal-Carou. 2002. Influence of starter and nonstarter on the formation of biogenic amine in goat cheese during ripening. J. Dairy Sci. 85:2471-2478.

Ogier, J. C., O. Son, A. Gruss, P. Tailliez, and A. Delacroix-Buchet. 2002. Identification of the bacterial microflora in dairy products by temporal temperature gradient gel electrophoresis. Appl. Environ. Microbiol. 68:3691-3701.

Platteeuw, C., G. Simons, and W. M. de Vos. 1994. Use of the Escherichia coli $\beta$-glucuronidase (gusA) gene as a reporter gene for analyzing promoters in lactic acid bacteria. Appl. Environ. Microbiol. 60:587-593.

Powell, H. A., M. C. Gooding, S. D. Garrett, M. B. Lund, and R. A. McKee. 1994. Proteinase inhibition of the detection of Listeria monocytogenes in milk using the polymerase chain reaction. Lett. Appl. Microbiol. 18:5961.

Raibaud, P., M. Caulet, J. V. Galpin, and G. Mocquot. 1961. Studies on the bacterial flora of the alimentary tract of pigs. II. Streptococci: Selective enumeration and differentiation of the dominant group. J. Appl. Bacteriol. 24:285-306.

Roig-Sagués, A. X., A. P. Molina, and M. M. Hernández-Herrero. 2002. Histamine and tyramine-forming microorganisms in Spanish traditional cheeses. Eur. Food Res. Technol. 215:96-100.

Silla Santos, M. H. 1996. Biogenic amines: Their importance in food. Int. J. Food Microbiol. 29:213-231.

Takahashi, H., B. Kimura, M. Yoshikawa, and T. Fujii. 2003. Cloning and sequencing of the histidine decarboxylase genes of gramnegative, histamine-producing bacteria and their application in detection and identification of these organisms in fish. Appl. Environ. Microbiol. 69:2568-2579.

Thompson, J. D., D. G. Higgins, and T. J. Gibson. 1994. CLUSTAL W: Improving the sensitivity of progressive multiple sequence alignment through sequence weighting, position-specific gap penalties and weight matrix choice. Nucleic Acids Res. 22:4673-4680.

Wittwer, C. T., M. G. Herrmann, A. A. Moss, and R. P. Rasmussen. 1997. Continuous fluorescence monitoring of rapid cycle DNA amplification. Biotechniques 22:130-131, 134-138.

Wohrl, S., W. Hemmer, M. Focke, K. Rappersberger, and R. Jarisch 2004. Histamine intolerance-like symptoms in healthy volunteers after oral provocation with liquid histamine. Allergy Asthma Proc. 25:305-311. 